\title{
PENGUATAN MANAJEMEN PENINGKATAN MUTU BERBASIS SEKOLAH (MPMBS) MELALUI IMPLEMENTASI KURIKULUM 2013
}

\author{
ERMI SOLA \\ Fakultas Tarbiyah dan Keguruan \\ Universitas Islam Negeri Alauddin Makassar
}

\begin{abstract}
:
School Based Management is basically giving the freedom for a school to manage all the activities at school in order to reach the goals effectively and efficiently. Office of Educational Research and Improvement (the US Department of Education, in Sutjipto, 2000) defines that School Based Management is a strategi to improve education by transferring significant responsibility from state and district offices to individual schools... provides prinicipals, teachers, students and parents greater control over the education process by giving them responsibility for decision about the budget, personnel, and the curriculum. Curriculum 2013 is aimed at preparing Indonesian citizens. especially students to have qualified life skills as individuals and or citizens who believe in God, productive, creative, innovative, and affective.
\end{abstract}

Keywords: School Based Management, Implementation of Curriculum 2013

\section{PENDAHULUAN}

paya meningkatkan kualitas pendidikan terus-menerus dilakukan baik secara konvensional maupun melalui kegiatan-kegiatan inovatif. Di antara kegiatan-kegiatan tersebut antara lain berbagai pelatihan peningkatan kompetensi guru, pengadaan buku dan alat pelajaran, perbaikan sarana dan prasarana pendidikan, dan peningkatan mutu manajemen sekolah. Namun demikian, berbagai indikator mutu pendidikan belum menunjukkan peningkatan yang berarti. Iklim birokratik, dan sentralistik, dalam sistem pendidikan yang terjadi selama ini dianggap sebagai salah satu penyebab keterpurukan mutu pendidikan. Sekolah terkungkung oleh kekuasaan mulai tingkat pusat hingga daerah sehingga kepala sekolah dan guru-guru sebagai pihak yang paling memahami realitas pendidikan berada pada posisi yang tidak berdaya atau dikendalikan. Pemberlakuan "Undang-Undang Republik Indonesia Nomor 22 Tahun 1999 tentang Pemerintah Daerah" yang kemudian diikuti pedoman pelaksanaannya berupa "Peraturan Pemerintah Republik Indonesia Nomor 25 Tahun 2000 tentang Kewenangan Pemerintah dan Kewenangan Propinsi sebagai Daerah Otonomi" mengandung konsekuensi logis di bidang pendidikan, yaitu adanya perubahan manajemen pendidikan yang memiliki jiwa dan semangat otonomi. Manajemen pendidikan berbasis pusat yang dijalankan selama ini diubah menjadi manajemen pendidikan berbasis sekolah yang dikenal dengan istilah manajemen peningkatan 
mutu berbasis sekolah (MPMBS), atau lebih dikenal dengan manajemen berbasis sekolah (MBS). MBS merupakan salah satu model manajemen pendidikan yang berbasis pada otonomi, kemandirian sekolah dan aparat daerah dalam menentukan arah, kebijakan, serta jalannya pendidikan di di daerah masingmasing.

Seiring upaya pemerintah meningkatkan mutu pendidikan di Indonesia tersebut, Undang-undang Nomor 20 tahun 2003 tentang Sistem Pendidikan Nasional pasal 1 ayat (19) menyebutkan bahwa kurikulum adalah seperangkat rencana dan pengaturan mengenai tujuan, isi, dan bahan pelajaran serta cara yang digunakan sebagai pedoman penyelenggaraan kegiatan pembelajaran untuk mencapai tujuan pendidikan tertentu. Kurikulum 2013 merupakan pengembangan kurikulum berbasis kompetensi (KBK) tahun 2004 dan kurikulum tingkat satuan pendidikan (KTSP) 2006 yang mencakup kompetensi sikap, pengetahuan dan keterampilan secara terpadu. Pada awal mencuatnya rencana perubahan kurikulum 2006 yang menekankan pada kurikulum tingkat satuan pendidikan (KTSP) menjadi kurikulum 2013 menuai banyak sekali pro kontra dari berbagai kalangan akademisi maupun praktisi pendidikan dan non pendidikan. Semua masukan, baik berupa kritik dan saran, dijadikan bahan kajian bagi pemerintah. hingga akhirnya saat ini kurikulum 2013 sudah memasuki tahap implementasi walau masih terbatas. Pada tahun ajaran 2013/2014 kurikulum 2013 di tingkat SD/MI dilaksanakan pada kelas I dan IV, tingkat SMP/MTs pada kelas VII dan tingkat SMA/MA/MAK/SMK kelas X. Pada tahun 2015/2016 kurikulum 2013 diharapkan dapat dilaksanakan di seluruh sekolah di Indonesia mulai kelas I sampai XII (http://news.detik.com/read/2013/07/14/162017/10/1/6).

\section{PEMBAHASAN}

\section{Konsep Dasar, Tujuan, dan Pelaksanaan Manajemen Berbasis Sekolah (MBS)}

Istilah manajemen dan administrasi memiliki pengertian yang selaras karena keduanya mempunyai unsur-unsur yang sama, seperti adanya serangkaian aktivitas, adanya keterlibatan sejumlah orang, dan tujuan yang telah disepakati sebelumnya. Manajemen pada prinsipnya merupakan the process of getting activities completed (Robbins dan de Cenzo, 1995: 4). Lebih spesifik, Bovee, at.al. (1993: 5) mendefinisikan manajemen sebagai "The process of attaining organizational goals by effectively and efficiently planning, organizing, leading and controlling the organization's human, physical, financial, and information resources" (proses untuk mencapai tujuan organisasi yang secara efektif dan efisien merencanakan, mengorganisasikan, mengarahkan, dan mengawasi orangorang yang terlibat di dalamnya, hal-hal yang bersifat fisik, keuangan, dan sumbersumber informasi). Pengertian senada juga dikemukakan oleh Stoner dan Freeman (1989: 3) bahwa "Management is the process of planning, organizing, leading, and controlling the work of organization members and of using all available 
organizational resources to reach stated organizational goals" (serangkaian proses atau aktifitas mulai dari perencanaan, pengorganisasian, pengarahan, dan pengawasan para anggota sebuah organisasi dengan memanfaatkan segenap sumber daya yang tersedia dalam usaha mencapai tujuan organisasi yang telah ditetapkan). Sedangkan administrasi menurut Bafadal (2003: 38) dengan mengutip dari Siagian (1981: 3) menjelaskan bahwa administrasi merupakan keseluruhan proses kerja sama antara dua orang manusia atau lebih yang berdasarkan rasionalitas tertentu untuk mencapai tujuan yang telah ditetapkan sebelumnya. Atau segenap proses penyelenggaraan dalam setiap usaha kerja sama sekelompok orang untuk mencapai tujuan tertentu (The Liang Gie, 1983: 9 dalam Bafadal, 2003: 38). Kedua pengertian tersebut bermakna bahwa administrasi merupakan keseluruhan proses atau bentuk kerja sama minimal dua orang dalam rangka mencapai tujuan yang telah disepakati bersama.

Manajemen Peningkatan Mutu Berbasis Sekolah (MPMBS) atau lebih dikenal dengan Manajemen Berbasis Sekolah (MBS) memiliki sejumlah istilah lain dengan pengertian yang selaras. Istilah-istilah tersebut antara lain site-based management, delegated management, school authonomy, dan local management of school (Bafadal, 2003: 81). Secara konseptual, MBS merupakan proses manajemen sekolah yang diarahkan untuk meningkatkan mutu pendidikan, yang secara otonomi direncanakan, diorganisasikan, dilaksanakan, dan dievaluasi dengan melibatkan semua stakeholder sekolah (Bafadal, 2003: 82). David (1989 dalam Bafadal) menerjemahkan MPMBS sebagai otonomi sekolah yang dibarengi dengan pembuatan keputusan partisipatori. Caldwell (1990: 303-304) mengemukakan bahwa MPMBS merupakan kewenangan pengalokasian berbagai sumber daya yang didesentralisasikan.

"School-site or school-based management... are all approaches to the management of the public schools or systemic private schools where in there is significant and consistent decentralization to the school level of authority to make decisions related to allocation of resources defined broadly toinclude knowledge, technology, power, material, people, time and money. The school remains accountable to a central authority for the manner in which resources are allocated".

Secara operasional MPMBS merupakan “Keseluruhan proses pendayagunaan berbagai komponen pendidikan dalam rangka peningkatan mutu pendidikan yang diupayakan sendiri oleh kepala sekolah bersama semua pihak yang terkait atau berkepentingan dengan mutu pendidikan (Bafadal, 2003: 84). Komponen dalam pengertian ini mencakup kurikulum dan pembelajaran, kesiswaan, kepegawaian, sarana prasarana, dan keuangan secara mandiri. Artinya, dikelola sendiri (selfmanaging), dirancang sendiri (self-designing/self-planning), diorganisir sendiri (selforganizing), diarahkan sendiri (self-directing), dan dikontrol/dievaluasi sendiri (selfcontrolling/evaluating) oleh semua pihak terkait. 
Menurut Dirjen Dikdasmen (2000) MPMBS bertujuan untuk memandirikan atau memberdayakan sekolah melalui pemberian wewenang, keluwesan dan sumber daya untuk meningkatkan mutu sekolah. Dengan kemandiriannya ini, (1) sekolah sebagai lembaga pendidikan lebih mengetahui kekuatan, kelemahan, peluang, dan ancaman sehingga dapat memaksimalkan sumber daya yang tersedia guna memajukan sekolah, (2) sekolah dapat mengembangkan berbagai program sesuai kebutuhannya secara mandirii, (3) sekolah dapat mempertanggung jawabkan mutu pendidikan kepada orang tua, masyarakat, pemerintah, dan (4) sekolah dapat bekompetisi secara sehat dalam rangka peningkatan mutu. Levavic (1995 dalam Bafadal, 2003: 86) menjelaskan tiga tujuan MBS, yaitu: (1) efisiensi; MBS sangat membantu dalam peningkatan mutu pendidikan berkenaan dengan efisiensi sumber daya manusia, (2) efektifitas; MBS sangat membantu dalam peningkatan mutu pendidikan melalui peningkatan kualitas PBM, dan (3) tanggung jawab; dengan respon terhadap siswa lebih besar.

Menurut Bailey dalam Slamet (2000), hal pertama yang harus difahami dari konsep MBS adalah desentralisasi. Konsep desentralisasi merupakan azas MBS yang memberi penekanan pada: (1) fleksibilitas pengambilan keputusan sekolah akan tumbuh dan berkembang dengan subur, sehingga keputusan dapat dibuat "sedekat" mungkin dengan kebutuhan sekolah; (2) akuntabilitas/ pertanggungjawaban terhadap masyarakat (majelis/ komite sekolah, orang tua peserta didik, publik) dan pemerintah meningkat; dan (3) kinerja sekolah akan meningkat (efektivitasnya, kualitasnya, efisiensinya, produktivitasnya, inovasinya, profitabilitasnya, kualitas kehidupan kerjanya, dan moralnya).

Ada beberapa asumsi dasar mengapa MBS diterapkan sebagai upaya dalam meningkatkan pengelolaan dan peningkatan mutu pendidikan. Pertama, yaitu sekolah dipandang sebagai suatu lembaga layanan jasa pendidikan yang memposisikan kepala sekolah sebagai manajer pendidikan. Kepala sekolah dituntut untuk bertanggung jawab atas seluruh komponen sekolah, dan harus berupaya meningkatkan mutu pelayanan dan mutu hasil belajar yang berorientasi kepada pemakai, baik internal (siswa), maupun eksternal (masyarakat), pemerintah, maupun lembaga industri dan dunia kerja. Kedua, yaitu MBS dapat efektif penerapannya jika didukung oleh sistem berbagi kekuasaan (power sharing) antara pemerintah pusat dan pemerintah daerah (provinsi dan kabupaten /kota) dalam pengelolaan sekolah. Ketiga yaitu sekolah paling mengetahui kekuatan, kelemahan, peluang dan ancaman bagi dirinya, sehingga dia dapat mengoptimalkan pemanfaatan sumber daya yang tersedia untuk memajukan sekolahnya. Sekolah pasti mengetahui dengan tepat kebutuhan lembaganya, khususnya input pendidikan yang akan dikembangkan dan didayagunakan dalam proses pendidikan sesuai dengan tingkat perkembangan dan kebutuhan peserta didik. Selanjutnya Slamet (2000), mengemukakan strategi utama yang perlu ditempuh dalam melaksanakan manajemen berbasis sekolah: 
1. Mensosialiasikan konsep manajemen berbasis sekolah keseluruh warga sekolah, yaitu guru,siswa, wakil-wakil kepala sekolah, konselor, karyawan dan unsur-unsur terkait lainnya (orangtua murid, pengawas, wakil kandep, wakil kanwil, dsb.) melalui seminar, diskusi, forum ilmiah, dan media masa. Hendaknya dalam sosialisasi ini juga dibaca dan dipahami sistem, budaya, dan sumber daya sekolah yang ada secermat-cermatnya dan direfleksikan kecocokannya dengan sistem, budaya, dan sumber daya yang dibutuhkan untuk penyelenggaraan manajemen berbasis sekolah.

2. Melakukan analisis situasi sekolah dan luar sekolah yang hasilnya berupa tantangan nyata yang harus dihadapi oleh sekolah dalam rangka mengubah manajemen berbasis pusat menjadi manajemen berbasis sekolah. Tantangan adalah selisih (ketidaksesuaian) antara keadaan sekarang (manajemen berbasis pusat) dan keadaan yang diharapkan (manajemen berbasis sekolah). Karena itu, besar kecilnya ketidaksesuaian antara keadaan sekarang (kenyataan) dan keadaan yang diharapkan (idealnya) memberitahukan besar kecilnya tantangan (loncatan).

3. Merumuskan tujuan situasional yang akan dicapai dari pelaksanaan manajemen berbasis sekolah berdasarkan tantangan nyata yang dihadapi (butir 2). Segera setelah tujuan situasional ditetapkan, kriteria kesiapan setiap fungsi dan faktor-faktornya ditetapkan. Kriteria inilah yang akan digunakan sebagai standar atau kriteria untuk mengukur tingkat kesiapan setiap fungsi dan faktor-faktornya.

4. Mengidentifikasi fungsi-fungsi yang perlu dilibatkan untuk mencapai tujuan situasional dan yang masih perlu diteliti tingkat kesiapannya seperti pengembangan kurikulum, pengembangan tenaga kependidikan dan nonkependidikan, pengembangan siswa, pengembangan iklim akademik sekolah, pengembangan hubungan sekolah-masyarakat, pengembangan fasilitas, dan fungsi-fungsi lain.

5. Menentukan tingkat kesiapan setiap fungsi dan faktor-faktornya melalui analisis SWOT (Strength, Weakness, Opportunity, and Threat). Analisis SWOT dilakukan dengan maksud mengenali tingkat kesiapan setiap fungsi dari keseluruhan fungsi yang diperlukan untuk mencapai tujuan situasional yang telah ditetapkan. Berhubung tingkat kesiapan fungsi ditentukan oleh tingkat kesiapan masing-masing faktor yang terlibat pada setiap fungsi, maka analisis SWOT dilakukan terhadap keseluruhan faktor dalam setiap fungsi, baik faktor yang tergolong internal maupun eksternal. Tingkat kesiapan harus memadai, artinya, minimal memenuhi ukuran kesiapan yang diperlukan untuk mencapai tujuan situasional, yang dinyatakan sebagai: kekuatan, bagi faktor yang tergolong internal dan peluang, bagi faktor yang tergolong faktor eksternal. Sedang tingkat kesiapan yang kurang memadai, artinya tidak memenuhi 
ukuran kesiapan, dinyatakan sebagai kelemahan, bagi faktor yang tergolong faktor internal; dan ancaman, bagi faktor yang tergolong faktor eksternal.

6. Memilih langkah-langkah pemecahan masalah, yakni tindakan yang diperlukan untuk mengubah fungsi yang tidak siap menjadi fungsi yang siap. Selama masih ada persoalan, yang sama artinya dengan ada ketidaksiapan fungsi, maka tujuan situasional yang telah ditetapkan tidak akan tercapai. Oleh karena itu, agar tujuan situasional tercapai, perlu dilakukan tindakan-tindakan yang mengubah ketidaksiapan menjadi kesiapan fungsi. Tindakan yang dimaksud lazimnya disebut langkah-langkah pemecahan persoalan, yang hakekatnya merupakan tindakan mengatasi makna kelemahan dan/atau ancaman, agar menjadi kekuatan dan/atau peluang, yakni dengan memanfaatkan adanya satu/lebih faktor yang bermakna kekuatan dan/atau peluang.

7. Berdasarkan langkah-langkah pemecahan persoalan tersebut, sekolah bersama-sama dengan semua unsur-unsurnya membuat rencana untuk jangka pendek, menengah, dan panjang, beserta program-programnya untuk merealisasikan rencana tersebut. Sekolah tidak selalu memiliki sumber daya yang cukup untuk melaksanakan manajemen berbasis sekolah idealnya, sehingga perlu dibuat skala prioritas untuk rencana jangka pendek, menengah, dan panjang.

8. Melaksanakan program-program untuk merealisasikan rencana jangka pendek manajemen berbasis sekolah. Dalam pelaksanaan, semua input yang diperlukan untuk berlangsungnya proses (pelaksanaan) manajemen berbasis sekolah harus siap. Jika input tidak siap/tidak memadai, maka tujuan situasional tidak akan tercapai. Yang perlu diperhatikan dalam pelaksanaan adalah pengelolaan kelembagaan, pengelolaan program, dan pengelolaan proses belajar mengajar. Pemantauan terhadap proses dan evaluasi terhadap hasil manajemen berbasis sekolah perlu dilakukan. Hasil pantauan proses dapat digunakan sebagai umpan balik bagi perbaikan penyelenggaraan dan hasil evaluasi dapat digunakan untuk mengukur tingkat ketercapaian tujuan situasional yang telah dirumuskan. Demikian kegiatan ini dilakukan secara terus-menerus, sehingga proses dan hasil manajemen berbasis sekolah dapat dioptimalkan.

Selanjutnya, Bafadal (2003: 93-95) mengemukakan bahwa untuk terlaksananya program MBS dengan baik, bertumpu pada 4 pilar utama: (1) Pilar Mutu. MBS merupakan pendekatan manajemen yang menempatkan mutu pendidikan sebagai "kiblat" aktivitas manajemen - kurikulum, kesiswaan, sarana prasarana, kepegawaian, keuangan, dan peran serta masyarakat, (2) Pilar kemandirian. MBS merupakan model pengelolaan sekolah yang sangat menuntut adanya kemandirian seluruh personil sekolah untuk maju dengan sendirinya. (3) Pilar partisipasi. MBS merupakan model pengelolaan sekolah yang sangat 
menekankan pada partisipasi seluruh elemen terkait dengan peningkatan mutu pendidikan, dan (4) Pilar transparansi. MBS juga merupakan model pengelolaan yang menuntut transparansi, khususnya dalam pengelolaan keuangan. Agar MBS dapat diimplementasikan dengan baik maka beberapa persyaratan perlu diperhatikan seperti dikemukakan Volansky \& Friedman (2003) sebagai berikut:

- $\quad$ SBM must have the strong support of school staff.

- $\quad$ SBM is more successful if it is implemented gradually. It may take 5 years or more to implement SBM.

- School and district staff must be given administrative training, but also must learn how to adjust to new roles and channels of communication.

- $\quad$ Financial support must be provided to make training and time for regular staff meetings available.

- Central office administrators must transfer authority to principals, and principals in turn must share this authority with teachers and parents.

Pertama; MBS hanya bisa dimplementasikan jika mendapat dukungan kuat dari semua staff di sekolah. Semua ikut berpartisiapsi aktif dalam pengembangan sekolah ke arah yang lebih baik. Kedua, sering kita terjebak dalam implementasi dengan produk yang instant (langsung jadi). Padahal, MBS yang akan dilaksanakan dengan merubah paradigma guru dan semua stakeholder bukanlah hal yang mudah, sehingga memerlukan waktu sekitar 5 tahun atau bahkan lebih. Ketiga, pada tingkat kabupaten tidak saja memberikan pelatihan secara administratif tetapi juga bagaimana menunjukkan peran baru dalam berkomunikasi dengan semua pihak. Keempat, MBS harus didukung oleh dana yang memadai untuk pelatihan staf secara berkesinambungan. Kelima, pemerintah pusat secara nyata memberikan kewenangan kepada kepala sekolah, dan kepala sekolah harus dapat membagi kewenangan tersebut kepada guru dan orangtua/komite sekolah. Singkatnya, semua unsur sekolah, kepala sekolah, guru, dan semua stakeholder harus paham betul MBS, tugas dan tanggung jawab masing-masing. Di samping itu harus ada komitmen yang kuat dari semua pihak. Tentu saja akan ada hambatan dan kesalahan yang mungkin diperbuat tetapi kekurangan harus diterima dengan baik dan berilah penghargaan pada setiap sukses/kemajuan yang dicapai.

\section{Implementasi Kurikulum 2013}

Kurikulum menurut undang-undang Nomor 20 tahun 2003 tentang Sistem Pendidikan Nasional pasal 1 ayat (19) menyebutkan bahwa kurikulum adalah seperangkat rencana dan pengaturan mengenai tujuan, isi, dan bahan pelajaran serta cara yang digunakan sebagai pedoman penyelenggaraan kegiatan pembelajaran untuk mencapai tujuan pendidikan tertentu. Kurikulum 2013 merupakan kelanjutan pengembangan kurikulum berbasis kompetensi (KBK) tahun 2004 dan kurikulum tingkat satuan pendidikan (KTSP) 2006 yang mencakup kompetensi sikap, pengetahuan dan keterampilan secara terpadu. Mengingat 
kemajuan ilmu pengetahuan dan teknologi dewasa ini di berbagai bidang, tidak terkecuali bidang pendidikan, kebutuhan akan kehadiran kurikulum 2013 dirasakan sangat mendesak. Berbagai tantangan internal dan eksternal menjadikan kurikulum 2013 yang pada awal kehadirannya menuai polemik pro kontra tetap diimplementasikan mulai tahun ajaran 2013/2014 walau masih secara terbatas.

Berdasarkan Rasional Kurikulum 2013, Direktur Jenderal Pendididikan Islam Kementerian Agama RI 2013 di antara tantangan internal yang dihadapi adalah: (1) Tuntutan pendidikan yang mengacu kepada 8 standar nasional pendidikan yang meliputi standar pengelolaan, standar biaya, standar sarana prasarana, standar pendidik dan tenaga kependidikan, standar isi, standar proses, standar penilaian, dan standar kompetensi lulusan. (2) Perkembangan penduduk Indonesia dilihat dari pertumbuhan penduduk usia produktif. Tantangan eksternal meliputi:

1. tantangan masa depan, antara lain: (a) arus globalisasi (WTO, ASEAN Community, APEC, AFTA), (b) masalah lingkungan hidup, (c) kemajuan teknologi informasi, (d) konvergensi ilmu dan teknologi, (e) ekonomi berbasis pengetahuan, (f) kebangkitan industri kreatif dan budaya, (g) pergeseran kekuatan ekonomi dunia, (h) pengaruh dan imbas teknosains, (i) mutu, investasi dan transformasi sector pendidikan, (j) materi TIMSS dan PISA.

2. kompetensi masa depan; di antaranya (a) kemampuan berkomunikasi (b) kemampuan berfikir jernih dan kritis (c) kemampuan mempertimbangkan aspek moral suatu masalah (d) kemampuan menjadi WN yang bertanggung jawab (e) kemampuan untuk mengeri dan toleran terhadap perbedaan pandangan (f) kemampuan hidup dalam masyarakat global (g) memiliki minat yang luas dalam kehidupan (h) memiliki kesiapan bekerja (i) memiliki kecerdasan sesuai bakat/minat (j) memiliki rasa tanggung jawab terhadap lingkungan.

3. persepsi masyarakat, yakni: (a) terlalu menitikberatkan pada aspek kognitif (b) beban siswa terlalu berat (c) kurang bermuatan karakter.

4. perkembangan pengetahuan dan pedagogi, mencakup (a) neurologi (b) psikologi (c) discovery learning-obsevation based dan collaborative learning.

5. fenomena negatif yang mengemuka seperti: (a) tawuran pelajar (b) narkoba (c) korupsi (d) plagiarisme (e) kecurangan dalam ujian (f) gejolak masyarakat (social unrest)

Menyikapi kenyataan berbagai tantangan internal dan eksternal pendidikan, pemerintah berusaha melakukan terobosan-terobosan baru melalui implementasi kurikulum 2013. Dari tinjauan http://news.detik.com/read/2013/07/14 /162017/10/1/6 minggu 14/07/2013 terdapat 6 perubahan yang dapat dilakukan bersamaan dengan penerapan kurikulum 2013. 
1. Penataan sistem perbukuan. Selama ini buku ditentukan oleh penerbit, baik menyangkut isi maupun harga sehingga orang tua peserta didik harus menanggung jumlah pembayaran yang sangat besar. Khusus berkenaan dengan isi, berbagai kejanggalan bahkan kesalahan, entah disengaja atau keteleroran sering terjadi seperti yang terjadi di kabupaten Bogor pada buku pelajaran bahasa Indonesia kelas VI yang berisi cerita porno. Penataan sistem perbukuan dalam implementasi kurikulum 2013 dikelola oleh Pusat Kurikulum dan Perbukuan. Sedangkan substansi isi ditangani oleh tim pengarah dan pengembang kurikulum, dengan tujuan agar isi buku sesuai dengan tujuan instruksional umum dan khusus, dengan mutu yang diharapkan jauh lebih baik, serta harga dapat ditekan sampai pada tingkat kewajaran.

2. Penataan Lembaga Pendidik Tenaga Kependidikan (LPTK) terutama kesiapan pengadaan guru.

3. Penataan terhadap pola pelatihan guru. Dalam implementasi kurikulum 2013, pendekatan berbagai pelatihan untuk instruktur nasional, guru inti dan guru sasaran, disesuaikan antara materi dan model atau pola pelatihan. Untuk penjenjangan karir dan kepangkatan guru dilakukan dengan penilaian profesi guru secara bersamaan.

4. Memperkuat budaya sekolah melalui integrasi kurikuler, ko-kurikuler dan ekstra kurikuler, serta memaksimalkan peran guru BK.

5. Memperkuat NKRI melalui kegiatan pramuka, keagamaan, dll.

6. Memperkuat integrasi pengetahuan budaya-bahasa. Dalam kurikulum 2013, peran bahasa Indonesia sangat dominan sebagai saluran yang mengantarkan kandungan materi semua kompetensi yang terdapat di setiap mata pelajaran kepada peserta didik. Kandungan materi semua kompetensi tersebut harus bersifat kontekstual sehingga menjadikan pembelajaran peserta didik bermakna.

\section{PENGUATAN MPMBS MELALUI IMPLEMENTASI KURIKULUM 2013}

Program MPMBS yang menitikberatkan pada kewenangan--kepala--sekolah dalam mengelola sumber daya pendidik dan tenaga kependidikan lainnya yang terdapat di setiap sekolah akan semakin kuat melalui implementasi kurikulum 2013. Di antara kegiatan yang diadakan pemerintah yang berkaitan erat dengan penguatan MPMBS melalui implementasi kurikulum 2013 adalah kegiatan yang dilaksanakan oleh Badan Pengembangan Sumber Daya Manusia Pendidikan dan Kebudayaan (BPSDMPK) dan Penjaminan Mutu Pendidikan (PMP) berupa pelatihan bagi para guru, kepala sekolah, dan pengawas. Kegiatan pelatihan tersebut dimaksudkan agar para pelaksana pendidikan ini memahami hakikat dan tujuan pengembangan kurikulum 2013 sehingga dapat mengimplikasikannya di sekolah masing-masing. Secara detail, bagi para guru, pelatihan tersebut ditujukan agar para guru mampu melaksanakan tugasnya secara benar sesuai tuntutan 
kompetensi lulusan, isi, proses pembelajaran dan penilaian yang terdapat dalam penjabaran kurikulum 2013. Bagi para kepala sekolah, pelatihan ditujukan agar setiap kepala sekolah mampu mengerahkan berbagai sumber daya yang dimiliki guna menjamin keterlaksanaan implementasi kurikulum 2013. Sementara bagi para pengawas, melalui pelatihan ini diharapkan mereka mampu memberikan bantuan teknis secara benar kepada kepala sekolah, para guru dan tenaga kependidikan lainnya dalam mengatasi berbagai hambatan dalam pengimplikasian kurikulum 2013.

Implementasi kurikulum 2013 dalam kaitannya dengan program MPMBS, yang berfokus pada otonomi sekolah, pada prinsipnya merupakan tanggung jawab kepala sekolah sebagai pimpinan pendidikan di sekolahnya. Sebagai manajer pendidikan di sekolahnya, kepala sekolah harus mampu mempengaruhi dan menggerakkan para guru dan tenaga kependidikan lainnya serta segenap sumber daya yang dimiliki sekolah dalam upaya meningkatkan mutu pendidikan melalui suksesnya implementasi kurikulum 2013. Kepala sekolah harus memiliki kemampuan manajerial yang handal, komitmen yang kuat untuk memajukan sekolahnya dan semangat juang yang besar dalam berbuat sehingga tidak ada lagi alasan untuk tidak berhasil dalam pelaksanaan kurikulum 2013. Dengan fungsifungsi manajerial yang melekat pada dirinya, kepala sekolah harus mampu merencanakan (planning) berbagai program dan kalender pendidikan secara terstruktur dan sistematis, baik untuk rentang waktu yang panjang, menengah, ataupun pendek. Perencanaan yang tepat akan sangat efektif dalam proses pelaksanaan maupun pengontrolan dan evaluasi pada tahapan akhir dari fungsifungsi manajerial seorang kepala sekolah. Dalam fungsi organisasi (organizing), kepala sekolah dituntut untuk mampu mengorganisir arus kerja setiap individu dalam struktur organisasi yang jelas dan transparan. Kepala sekolah harus piawai menentukan siapa mengerjakan apa dan dengan cara bagaimana, sehingga tujuan pendidikan nasional dan institusional secara konseptual dapat dicapai melalui implementasi kurikulum 2013. Job description yang jelas tidak berarti menjadikan para guru dan tenaga kependidikan lainnya kaku dan terkotak-kotak dalam melaksanakan tugas kependidikannya. Pendelegasian wewenang tetap dapat dan harus dijalankan karena proses belajar mengajar harus terus berjalan (the show must go on) dalam situasi yang kondusif (prinsip PAKEM). Dalam fungsi pelaksanaan (actuating) kepala sekolah harus mampu mengerahkan seluruh sumber daya manusia dan sarana prasarana yang dimiliki sekolah untuk bekerja dengan penuh semangat dan percaya diri. Kepala sekolah berkewajiban memotivasi para guru dan tenaga kependidikan lainnya dalam melaksanakan tugas kependidikan mereka, mengerti dan memberikan solusi berbagai masalah yang dihadapi para bawahannya, dan melakukan supervisi yang edukatif (educational education) berkenaan dengan pelaksanaan tugas-tugas belajar mengajar sehingga prinsip PAKEM terpelihara dengan baik. Pengawasan/pengendalian (controlling) 
merupakan fungsi pamungkas dari fungsi-fungsi manajerial seorang kepala sekolah. Dalam pelaksanaan fungsi ini, kepala sekolah harus memastikan bahwa aktivitas yang telah dilakukan selama rentang waktu tertentu berjalan sesuai dengan perencanaan yang telah dibuat dan disepakati bersama. Dalam melaksanakan proses pengawasan, kepala sekolah harus mampu menetapkan standar kinerja, mengukur kinerja, membandingkan kinerja dengan standar yang telah ditetapkan, mengambil tindakan korektif jika didapati penyimpangan.

Artinya, penguatan MPMBS melalui pengejawantahan kurikulum 2013 dengan memaksimalkan fungsi-fungsi manajerial kepala sekolah tidak terlepas dari kemampuan kepala sekolah dalam memimpin para guru dan tenaga kependidikan yang dimiliki. Kepemimpinan pada hakikatnya merupakan perpaduan kepribadian (personality), kemampuan (skill) dan kesanggupan (capability) yang melekat pada diri seorang pemimpin-kepala sekolah dalam usahanya mempengaruhi individu atau kelompok untuk mencapai tujuan yang telah ditetapkan. Kepala sekolah sebagai manajer pendidikan mempunyai beragam tugas yang dapat membantunya dalam mempengaruhi dan menggerakkan para bawahannya menuju tujuan yang telah disepakati bersama. Stoner (dalam Wahjosumidjo, 1987; 35) menyebutkan ke 8 tugas tersebut adalah:

1) the manager assumes responsibility, 2) the manager must balance competing goals, 3) the manager is a conceptual thinker, 4) the manager works with dan through other people, 5) the manager is a mediator, 6) the manager is a politician, 7) the manager ia a diplomat, dan 8) the manager makes difficult decisions.

Pertama, sebagai seorang manajer kepala sekolah bertanggung jawab penuh atas sukses tidaknya pelaksanaan program pendidikan dan pembelajaran di sekolah. Tanggung jawab tersebut meliputi keberhasilan kepala sekolah dalam menangani berbagai masalah yang dihadapi setiap bawahan, baik masalah yang bersifat umum maupun pribadi, dan mengevaluasi tugas-tugas pendidikan dan pembelajaran yang dilaksanakan para guru dan tenaga kependidikan lainnya. Hal ini dapat dilakukan dengan efektif melalui kerja sama yang harmonis antara kepala sekolah dengan semua sumber daya yang berada di bawah kepemimpinannya. Kedua, kepala sekolah harus mampu menciptakan dan menjaga keseimbangan iklim sekolah yang stabil, memberikan prioritas terhadap tugas apa dan pendelegasiannya kepada siapa sehingga tujuan pendidikan dan pembelajaran dapat dicapai dengan efektif dan efisien. Ketiga, kepala sekolah merupakan konseptor yang harus mampu berfikir kritis analitis, sistematis, dan menyeluruh serta mampu menganalisis setiap persoalan di sekolah sehingga berbagai persoalan yang dihadapi dapat diselesaikan secara efektif dan efisien. Keempat, untuk melaksanakan dan menyelesaikan berbagai tugas dan tanggung jawabnya, jelas kepala sekolah tidak akan mampu bekerja sendiri. kepala sekolah 
memerlukan orang lain, baik para guru dan tenaga kependidikan lainnya, kolega sejawat, atasan, maupun stakeholders lainnya. Singkatnya, kepala sekolah harus mampu membangun channel of communication dengan setiap orang yang berkaitan dan bersentuhan, langsung maupun tidak, dengan dunia pendidikan dan pengajaran. Kelima, kepala sekolah sebagai seorang mediator bertanggung jawab memediasi berbagai pertikaian, baik internal ataupun eksternal, sehingga tidak berimbas terhadap semangat dan kinerja para bawahan. Keenam yang merangkum aspek ketujuh dan delapan, kepala sekolah sebagai politisi dan diplomat harus mampu bertindak persuasive dan menjadi wakil bagi para bawahannya, terutama dalam berbagai keputusan penting dan terkadang pelik usaha peningkatan mutu pendidikan di sekolah.

\section{KESIMPULAN}

Penguatan Manajemen Peningkatan Mutu Berbasis Sekolah (MPMBS) melalui implementasi kurikulum 2013 merupakan langkah yang harus dilakukan oleh semua perangkat pendidikan mulai dari stakeholder's yang berkaitan dengan kepentingan pelaksanaan pendidikan sampai para guru dan semua elemen yang bersentuhan langsung dengan proses belajar dan mengajar di sekolah. Implementasi kurikulum 2013 dengan segenap perubahan yang mengiringinya, seperti: kompetensi lulusan, kedudukan mata pelajaran (isi), pendekatan isi, struktur kurikulum, proses pembelajaran, penilaian hasil belajar, dan ekstra kurikuler jelas menuntut para pelaku pendidikan terutama para guru menerapkan metode dan pola pembelajaran yang berbeda dengan kurikulum-kurikulum sebelumnya. Pola pembelajaran pada kurikulum 2013 berpusat pada peserta didik, interaktif (melibatkan guru-peserta didik- masyarakat-lingkungan alam, sumber/media lainnya), berbasis jejaring (peserta didik bisa belajar dari siapapun, dan media apapun termasuk internet), model pembelajaran melalui pendekatan sains (peserta didik yang aktif mencari dan menemukan), berbasis tim, berbasis multi media, mengembangkan potensi khusus peserta didik, dari mono discipline knowledge menjadi multi discipline knowledge, dan bersifat kritis.

Semua perubahan ini sangat menuntut soft skill kepala sekolah, yang merupakan motor penggerak sukses-gagalnya pelaksanaan program pendidikan dan pembelajaran di sekolah. Kepala sekolah dituntut untuk bersikap tegas namun tetap luwes dalam menjalankan fungsi-fungsi kepemimpinannya, memotivasi dan menggerakkan segenap sumber daya dan dana yang tersedia secara efektif dan efisien. Efektivitas dan efisiensi pelaksanaan fungsi-fungsi manajerial disertai tugas-tugas kepemimpinan kepala sekolah menjadi bagian penting pengimplikasian kurikulum 2013 dalam upaya peningkatan mutu pendidikan berbasis sekolah. 


\section{DAFTAR PUSTAKA}

Bafadal, Ibrahim. 2003. Manajemen Peningkatan Mutu Sekolah Dasar. Jakarta: Bumi Aksara

Bovee, at. al. 1993. Management. New York: McGraw-Hill, Inc.

Caldwell, B. J. 1990. Education Reform through School-Site Management: An International Perspectives on Restructuring in the Education. Advances inResearch and Theories of School Management and Education Policy. 1: 303-333

Dacholfany, M. Ihsan dan Yuzana, Evi. Manajemen Berbasis Sekolah. MBS net. Mei 15, 2009

http://news.detik.com/read/2013/07/14/162017/10/1/6 minggu 14/07/2013

Kristianty, Theresia. 2005. Peningkatan Mutu Pendidikan Terpadu dengan Konsep Daming. Pdf. Adobe Reader (Hal. 106-112)

Robins, Stephen P., de Cenzo, David A. 1995. Fundamentals of Management; Essential Concepts and Applications. New Jersey: Prentice-Hall International, Inc.

Slamet. 2000. Manajemen Berbasis Sekolah. Jurnal Pendidikan dan Kebudayaan No. 027 November 2000.

Stoner, James A., Freeman, R. Edward. Management. 4th Edition. 1989. New Jersey: Prentice-Hall International. Inc.

Volansky, A., \& Friedman, I. A. 2003. School-based management: An International Perspective. Israel: Ministry of Education.

Wahjosumidjo. 1987. Kepemimpinan dan Motivasi. Ghalia Indonesia; 1987 